\title{
Nutritional Evaluation Of Toasted White Sesame Seed Meal Sesamum Indicum As A Source Of Methionine On Growth Performance, Carcass Characteristics, Haematological And Biochemical Indices Of Finisher Broiler Chickens
}

\author{
B.Yakubu and B. Alfred \\ Department of Animal Science and Range Management, Federal University of Technology, \\ P.M. B. 2076, Yola, Nigeria
}

\begin{abstract}
One hundred and fifty (150) Anak-2000 day-old broiler chicks were used to investigate the effect of toasted white sesame seed meal (TWSSM) as a source of methionine on growth performance, carcass characteristic, haematological and biochemical indices of broiler finisher chickens. The chicks were randomly assigned to five dietary treatments consisting of three replicates of ten chicks per replicate in a completely randomized design. The dietary treatments were TWSSM at 0, 4, 8, 12 and $16 \%$ representing treatments 1, 2, 3, 4 and 5 respectively. For eight weeks, data were collected on feed intake, weight gain and feed conversion ratio. At the end of the experiment, 6 birds were randomly selected from each treatment and slaughtered to determine the effect of TWSSM on carcass characteristics and internal organs weight. Blood samples were also collected from 6 birds in each treatment for haematological and biochemical studies. Results from growth performance revealed that all the growth parameters were not significantly $(P>0.0)$ affected by the levels of TWSSM supplementation except feed intake which was significantly $(P<0.05)$ higher in treatment $1(0 \%)$. The values for carcass characteristics and internal organs weight also did not show any significant difference $(P>0.05)$ across the treatments. Significant $(P<0.05)$ variation was however observed in the values of abdominal fat which increased with increasing level of TWSSM. Supplementation level of TWSSM did not affect the haematological parameters while biochemical indices such as protein, urea and glucose were significantly influenced by the treatment diets. It appears therefore that supplementation of TWSSM at 18\% did not affect the performance and blood profile of broiler finisher chickens.
\end{abstract}

Key words: white sesame, performance, broiler, carcass, haematology, methionine

\section{Introduction}

In Nigeria, the population growth rate and demand for food is over 3\% while growth rate in food production is between $1.0-1.5 \%$ leaving a short fall of $1.5-2 \%$ in annual food supplies. There is also the imbalance in food supplies, between plant and animal sources. Plant sources contribute over $75 \%$ of Nigerian total food supplies and animal sources accounts for only $25 \%$. Nigeria still remains among the least animal protein consumers in Africa. The average animal protein intake for Africa is $11 \mathrm{~g} / \mathrm{head} /$ day while the average value for Nigeria is $7.5 \mathrm{~g} / \mathrm{head} / \mathrm{day}$ (Lamorde, 1998). This has been attributed to high and rising cost of feeds which accounts for more than $85 \%$ of the total cost of production (Umeh and Udo, 2002). Feeds formulated with synthetic methionine which is not always accessible to rural farmers' accounts for $60-75 \%$ cost of raising commercial poultry (Adejoro, 2004). In recent years, the cost of synthetic methionine has kept increasing in Nigeria with a resultant increase in the cost of the finished feed (Diarra and Usman, 2008). Essien et al. (2005) observed that when a diet is supplemented with synthetic methionine at $0.5 \%$ supplementation level, it represents up to $10.26 \%$ of the total cost of producing feed in Nigeria. This apparently makes it difficult for rural farmers to be self engaged in commercial poultry business.

Several researchers have advocated for the use of alternative sources of synthetic methionine that is readily available and cheaper (Aduku, 1992; Oluyemi and Roberts, 2000; Ngele et al., 2011). One of the vegetable plant sources that can supplement synthetic methionine is sesame seed. Sesame (Sesamum indicum L.) otherwise known as sesamum or benniseed, member of the family Pedaliaceae, is one of the most ancient oil seed crop known to mankind. The major producing areas of sesame in Nigeria are Nasarawa, Jigawa, Benue, Yobe, Niger, Kano, Katsina, Kogi, Gombe, Plateau and Taraba States (NAERLS, 2010). Sesame seed is rich in protein and minerals like potassium, phosphorous, magnesium, calcium and sodium. The protein content has been reported by many workers; 18-25\% (Bonchani et al., 2010), 20\% (Nzkou et al., 2009), 22.30\% (Olomu, 2011 ) and $22-25 \%$ (Tunde-Akintunde et al., 2012). The protein is rich in essential amino-acids which include leucine, arginine and methionine but is low in lysine (Banerjee, 1998). Sesame seeds are also good sources of minerals and vitamins such as manganese, copper, calcium, vitamin B1 and vitamin E (Biswas et al., 2001; 
Ojiako et al., 2010) and in addition to the highly absorbable spectrum of vitamin E, they increase its bioactivity in the body (Cooney et al., 2001).

In poultry nutrition, sesame seed has been used to supplement synthetic methione in laying hens (Diarra and Usman, 2008) and broilers (Agbulu et al., 2010), but there is paucity of information on the use of white toasted sesame seed as a supplement for synthetic methione in broiler finisher diets. This study therefore was aimed at evaluating toasted white sesame seed meal, Sesamum indicum as a source of methionine on growth performance, carcass characteristics, haematological and biochemical indices of broiler finisher chickens.

\section{Experimental site}

\section{Materials and methods}

The experiment was conducted at the Poultry Teaching and Research Farm of the Federal University of Technology, Yola. Yola lies between latitude $7^{\circ}$ and $11^{\circ} \mathrm{N}$ and longitude $11^{\circ}$ and $14^{\circ} \mathrm{E}$. Temperature in this climatic region is high in February to April because of high radiation, which is evenly distributed throughout the year. Maximum temperature in the state can reach up to $40^{\circ} \mathrm{c}$ particularly in April, while minimum temperature can be as low as $18^{\circ} \mathrm{c}$ between December and January. Mean monthly temperature range from $26.7^{\circ} \mathrm{c}$ in the South to $27.8^{\circ} \mathrm{c}$ in the North Eastern part of the state (Adebayo, 1999).

\section{Processing of white sesame seed}

White Sesame seed was obtained from a rural market in Girei, Adamawa state, North-Eastern Nigeria. The seeds were screened, winnowed and cleaned to remove dirt, sand, stones and other foreign particles. Using fire wood as a source of heat, $5 \mathrm{~kg}$ of Sesame seeds were placed in a wide open aluminum pan and toasted for about 15 minutes by stirring continuously with an aluminum spoon to prevent the burning of the seed coat and to enhance even distribution of heat. The toasting was arrested when pop sound was produced and the seeds slightly turned brown.

\section{Experimental birds, management and design}

One hundred and fifty (150) day old (Anak, 2000) white strain unsexed broiler chicks were purchased from a commercial poultry farm in Otta, Ogun state, South Western Nigeria. The birds were managed on a deep litter throughout the period of the experiment. Brooding was done at the first one week of the experiment and the chicks were fed on commercial broiler starter feed. Thereafter, the birds were randomly allotted to the five dietary treatments of 30 birds per treatment and were replicated three times with 10 birds per replicate in a completely randomized design. The birds were vaccinated routinely as described by Oleyemi and Roberts, (2000).

\section{Experimental diets}

Five dietary treatments were formulated with toasted white sesame seed meal (TWSSM) to replace synthetic methionine at $0.00,4.00,8.00,12.00$ and $16.00 \%$ in treatments 1 (control), 2, 3, 4 and 5 respectively (Table 1). The control treatment contained synthetic methionine while TWSSM was used in place of methionine in the other treatments. The TWSSM was analyzed for proximate composition and amino acid profile. The birds were fed the experimental diets and clean drinking water ad libitum for a period of 8 weeks.

Table 1: Composition of Broiler finisher diets

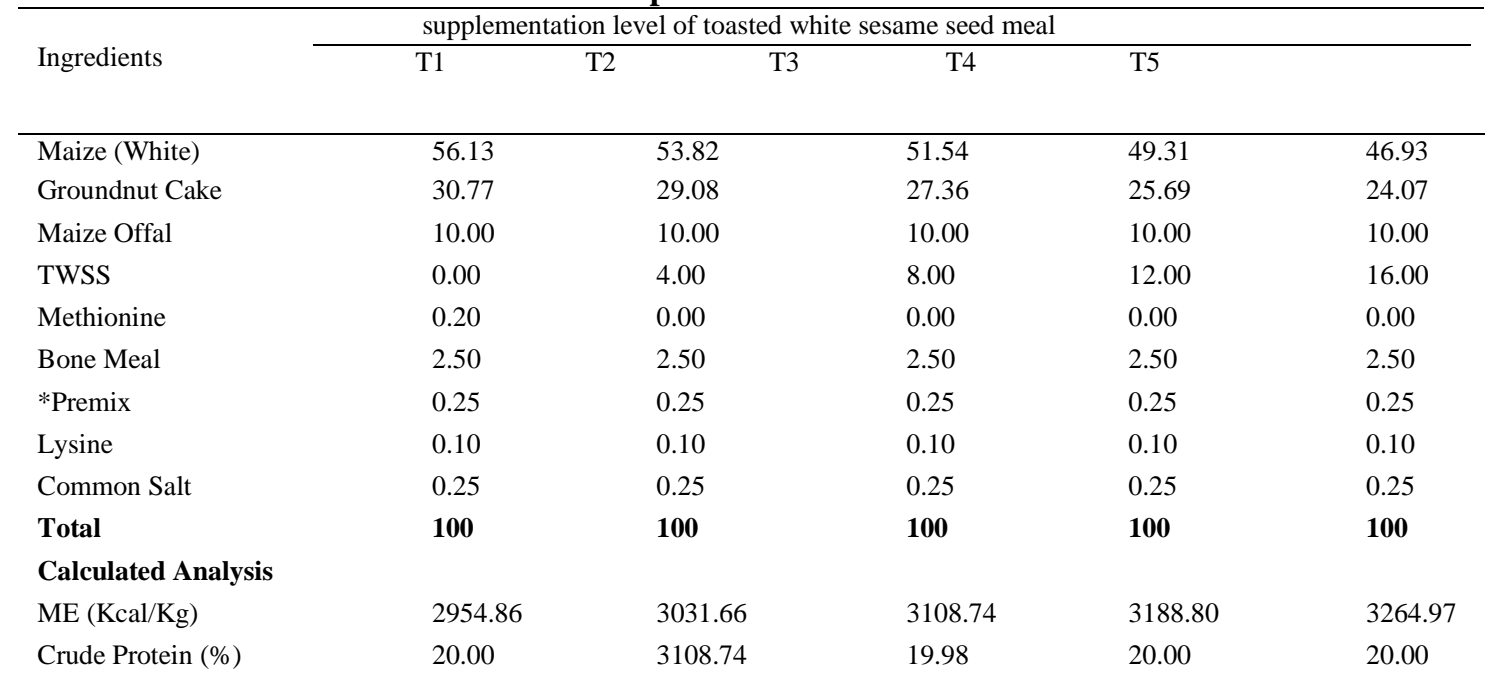


Nutritional Evaluation Of Toasted White Sesame Seed Meal Sesamum Indicum As A Source Of

$\begin{array}{llllll}\text { Crude Fibre (\%) } & 4.62 & 3.74 & 4.07 & 4.41 & 4.73 \\ \text { Calcium } & 0.97 & 1.01 & 1.05 & 1.09 & 1.12 \\ \text { Phosphorus } & 0.78 & 0.80 & 0.81 & 0.82 & 0.84 \\ \text { Methionine } & 0.46 & 0.27 & 0.30 & 0.30 & 0.32\end{array}$

*Vitamin-Mineral premix (Bio-mix) provides per Kg the following: Vitamin A500iu; Vitamin $\mathrm{D}_{3}, 888,000 \mathrm{iu}$; Vitamin E, 12,000mg; Vitamin $\mathrm{K}_{3}, 15,000 \mathrm{mg}$; Vitamin $\mathrm{B}_{1}$, 1000mg; $\mathrm{B}_{2}$, 2000mg; Vitamin $\mathrm{B}_{6}$, 1500mg; Niacin, 1200mg; Pantothenic acid, 2000mg; Biotin, 1000mg; Vitamin $\mathrm{B}_{12}$, 3000mg; Folic acid, 1500mg; Choline Chloride; 60,000mg, Manganese, 10,000mg Iron, 1500mg; Zinc, 800mg; Copper, 400mg; Iodine, 80mg; Cobalt 40mg; Selenium, 8000mg.

TWSS $=$ Toasted white sesame seed

\section{Data collection}

Data were collected on feed intake, weight gain, carcass and internal organs characteristics, haematological and biochemical indices. Feed intake was determined as the difference between the left over and the quantity of feed offered the previous day. Similarly, weight gain was determined as the difference between the final weight and initial weight. Feed conversion ratio was measured as an index of feed utilization for each treatment group and was calculated as the ratio of feed intake to weight gain.

Two birds from each replicate were randomly selected for carcass and internal organs measurements. The birds were tagged according to their replicates and fasted for 8hours to reduce the gastro-intestinal contents (Yakubu et al., 2012). The birds were individually weighed and slaughtered. The slaughtered birds were defeathered completely and the carcasses were plucked and the heads, necks and legs were removed and eviscerated weights were measured. The internal organs were carefully removed and weighed to determine their fresh weights. The internal organs weight was expressed as proportion of their body weight.

Blood samples for haematological and biochemical indices were collected from randomly selected birds from each of the replicates using sterile syringe into sterile bottles containing anti-coagulant (EDTA- ethylene diamine tetra-acetic acid) and another blood samples were collected without ant-coagulants for the determination of serum biochemical indices. The blood samples were analyzed for red blood cells (RBC), packed cell volume (PCV), haemoglobin ( $\mathrm{Hb})$, and white blood cells (WBC). The coagulated blood samples were also subjected to standard serum separation for total protein, globulin, albumin, urea, creatinine and, cholesterol. The mean corpuscular volume (MCV), mean corpuscular haemoglobin (MCH), and Mean corpuscular haemoglobin concentration (MCHC) were also determined as described by Sirios, (1995).

\section{Proximate analysis}

Proximate composition of the sesame seed and amino acid profile were analyzed according to the procedures described by AOAC (1990)

\section{Statistical analysis}

Data generated from for all the parameters measured were subjected to one way analysis of variance as described by Steel and Torrie (1980) and Duncan Multiple Range Test (Duncan, 1955) was used to separate treatment means.

\section{Results}

The results of proximate composition and amino acid profile of TWSSM are presented in Tables 2 and 3. Results showed that the seed contained $20.26 \%$ crude protein and $53.27 \%$ ether extract. The values for ash and crude fibre were 4.37 and $9.38 \%$ respectively. Nitrogen free extract was found to be $6.30 \%$ and total dry matter was $93.66 \%$. Amino acid profile of TWSSM as presented in Table 3 showed that it contained methionine 6.24 , lysine 3.23, valine 3.27, and arginine $8.93 \mathrm{~g} / 100 \mathrm{~g}$ concentration. Other amino acids include leucine, 5.37, phenylalnine, 7.81 , glycine, 7.31 and threoline, $4.25 \mathrm{~g} / 100 \mathrm{~g}$ concemtration.

Table 2: Proximate composition of toasted white sesame seed

\begin{tabular}{lc}
\hline Nutrient & Percentage \\
\hline Crude protein & 20.26 \\
Ether Extraction & 53.27 \\
Ash & 4.37 \\
Crude fibre & 9.38 \\
Nitrogen Free Extract & 6.38 \\
Moisture & 6.34 \\
Dry matter & 93.66 \\
\hline
\end{tabular}


Table 3: Amino acid profile of toasted white sesame seed

\begin{tabular}{lc}
\hline Amino Acid & $\mathbf{g} / \mathbf{1 0 0 g}$ concentration \\
\hline Arginine & 8.93 \\
Glycine & 7.31 \\
Histidine & 3.02 \\
Isoleucine & 3.92 \\
Leucine & 5.37 \\
Lysine & 3.23 \\
Methionine & 6.24 \\
Phenylalanine & 7.81 \\
Proline & 3.20 \\
Serine & 5.48 \\
Threoline & 4.25 \\
Valine & 3.27 \\
\hline
\end{tabular}

The results of final weight, average daily feed intake (ADFI), average daily weight gain (ADWG) and feed conversion ratio (FCR) are presented in Table 4. The initial weight range between 95.66g $-100.00 \mathrm{~g}$ while the final weight was between $1000.74 \mathrm{~g}-1144.17 \mathrm{~g}$ and they were all similar $(\mathrm{P}>0.05)$ across the treatments. There was a significant difference $(\mathrm{P}<0.05)$ in ADFI between the treatments with birds in treatment 1 having the highest $(78.43 \mathrm{~g})$ feed intake and lowest $(65.99 \mathrm{~g})$ in treatment 5. Result of ADWG was not significant and it range from 23.23 in treatment 5 to $27.76 \mathrm{~g}$ in treatment 1 . Similarly, FCR were not influenced by the dietary treatments as they were all similar across the treatments.

Table 4: Effects of TWSSM supplementation on growth performance of broiler finisher chickens

\begin{tabular}{|c|c|c|c|c|c|c|}
\hline \multirow[b]{2}{*}{ Parameters } & \multicolumn{5}{|c|}{ supplementation $\mathrm{t}$ levels of toasted white sesame seed meal } & \multirow[b]{2}{*}{ SEM } \\
\hline & 1 & 2 & 3 & 4 & 5 & \\
\hline Initial weight $(\mathrm{g})$ & 95.66 & 99.33 & 99.66 & 100.00 & 97.66 & $4.53^{\mathrm{ns}}$ \\
\hline Final weight $(\mathrm{g})$ & 1144.17 & 1043.12 & 1089.28 & 1021.84 & 1000.74 & $44.16^{\mathrm{ns}}$ \\
\hline ADFI $(g)$ & $78.43^{\mathrm{a}}$ & $72.56^{\mathrm{ab}}$ & $75.23^{\mathrm{ab}}$ & $69.16^{\mathrm{b}}$ & $65.99^{\mathrm{b}}$ & $1.96^{*}$ \\
\hline $\operatorname{ADWG}(\mathrm{g})$ & 27.76 & 25.38 & 26.49 & 24.44 & 23.23 & $1.28^{\mathrm{ns}}$ \\
\hline FCR & 2.82 & 2.85 & 2.84 & 2.83 & 2.84 & $0.10^{\mathrm{ns}}$ \\
\hline
\end{tabular}

$\mathrm{a}, \mathrm{b}$, Mean values on the row with different superscripts are significantly different $(\mathrm{P}<0.05)$ ADFI $=$ Average daily feed intake, $\mathrm{ADWG}=$ Average daily weight gain, $\mathrm{FCR}=$ Feed conversion ratio, SEM $=$ Standard error of mean

The results of carcass characteristics and internal organs weight are presented in Table 5. There were no significant differences $(\mathrm{P}<0.05)$ in all the parameters measured for both carcass characteristics and internal organs weight except for the abdominal fat which was significantly $(\mathrm{P}<0.05)$ higher in treatment 5 . Numerically, carcass weight was higher in Treatment 1 (1403.33g) and lowest in treatment $4(1106.44 \mathrm{~g})$. The dressing percent range was between $68.89 \%$ in treatment 2 to $64.44 \%$ in treatment 4 .

Table 5: Effect of TWSSM supplementation on carcass characteristics and internal organs weight of broiler finisher chickens

\begin{tabular}{|c|c|c|c|c|c|c|}
\hline \multirow{3}{*}{ Ingredients } & \multirow{2}{*}{\multicolumn{5}{|c|}{ supplementation levels of toasted white sesame seed meal }} & \\
\hline & & & & & & \\
\hline & \multicolumn{5}{|c|}{\begin{tabular}{ccccc}
\multicolumn{5}{c}{ supplementation levels of toasted white sesame seed meal } \\
$\mathrm{T} 1$ & $\mathrm{~T} 2$ & $\mathrm{~T} 3$ & $\mathrm{~T} 4$ & $\mathrm{~T} 5$
\end{tabular}} & \\
\hline Live weight (g) & 2043.33 & 1936.33 & 2044.66 & 1690.00 & 1700.00 & $142.13^{\mathrm{ns}}$ \\
\hline Slaughtered Weight (g) & 1919.66 & 1924.33 & 1848.33 & 1587.00 & 1629.00 & $121.18^{\text {ns }}$ \\
\hline Plucked weight $(\mathrm{g})$ & 1837.33 & 1753.33 & 1804.66 & 1537.66 & 1576.33 & $129.42^{\mathrm{ns}}$ \\
\hline Eviscerated Weight (g) & 1530.00 & 1440.33 & 1452.66 & 1200.00 & 1238.66 & $99.56^{\mathrm{ns}}$ \\
\hline Carcass weight $(\mathrm{g})$ & 1403.33 & 1334.00 & 1317.33 & 1106.66 & 1121.33 & $94.71^{\mathrm{ns}}$ \\
\hline Dressing \% & 68.54 & 68.89 & 64.44 & 65.28 & 66.07 & $1.37^{\mathrm{ns}}$ \\
\hline Internal Organs (\%) & & & & & & \\
\hline Liver weight $(\mathrm{g})$ & 1.57 & 2.09 & 1.74 & 1.62 & 1.80 & $0.11^{\mathrm{ns}}$ \\
\hline Heart weight (g) & 0.49 & 0.52 & 0.47 & 0.62 & 1.80 & $0.11^{\mathrm{ns}}$ \\
\hline Lungs weight (g) & 0.64 & 0.69 & 0.69 & 0.61 & 0.75 & $0.05^{\mathrm{ns}}$ \\
\hline Gizzard weight (g) & 1.68 & 1.70 & 1.78 & 2.05 & 1.07 & $0.19^{\mathrm{ns}}$ \\
\hline Kidney weight (g) & 0.01 & 0.02 & 0.01 & 0.02 & 0.01 & $0.00^{\mathrm{ns}}$ \\
\hline Pancreas Weight & 0.15 & 0.17 & 0.14 & 0.12 & 0.14 & $0.01^{\mathrm{ns}}$ \\
\hline GIT length $(\mathrm{cm})$ & 175.36 & 180.53 & 190.53 & 165.80 & 162.33 & $9.70^{\mathrm{ns}}$ \\
\hline GIT weight (g) & 2.50 & 3.36 & 3.29 & 3.31 & 3.31 & $0.30^{\mathrm{ns}}$ \\
\hline Caecal length $(\mathrm{cm})$ & 35.13 & 35.76 & 36.60 & 31.20 & 34.83 & $1.28^{\mathrm{ns}}$ \\
\hline Caecal weight (g) & 0.34 & 0.45 & 0.42 & 0.33 & 0.37 & $0.07^{\mathrm{ns}}$ \\
\hline Abdominal fat weight $(\mathrm{g})$ & $2.58^{\mathrm{b}}$ & $2.70^{\mathrm{b}}$ & $2.62^{\mathrm{b}}$ & $3.11^{\mathrm{b}}$ & $5.20^{\mathrm{a}}$ & $0.45^{*}$ \\
\hline
\end{tabular}

Ns $=$ Not significant $*=\mathbf{P}<\mathbf{0 . 0 5}$, SEM $=$ Standard error of means, GIT $=$ Gastro intestinal tract

The effects of TWSSM as a source of methione on haematological and biochemical indices are presented in Table 6. Packed cell volume (PCV), red blood cells (RBC), and haemoglobin ( $\mathrm{Hb}$ ) concentration was not 
affected by the supplementation of TWSSM for methione. The white blood cells (WBC) however, were significantly $(\mathrm{P}<0.05)$ different across the treatments as treatment $5(123.23)$ had significantly higher value than the other treatments. The mean corpuscular volume $(\mathrm{MCV})$, mean corpuscular haemoglobin $(\mathrm{MCH})$ and mean corpuscular haemoglobin concentration (MCHC) were not affected by the treatment diets. Similarly, neutrophils, monocytes and lymphocytes were also similar across the treatments. Significant differences were observed in values for protein, urea and glucose. The value for protein (34.00) and urea (2.06) in Treatment 1 was significantly higher than the other treatments, whereas glucose was significantly higher in treatments 4 (12.40) and 5 (12.13).

Table 6: Effects of TWSSM supplementation on haematological and biochemical indices of broiler finisher chickens

\begin{tabular}{|c|c|c|c|c|c|c|}
\hline \multirow[b]{2}{*}{ Parameters } & \multicolumn{5}{|c|}{ supplementation levels of toasted white sesame seed meal } & \\
\hline & $\mathrm{T} 1$ & $\mathrm{~T} 2$ & T4 & SEM & & \\
\hline $\mathrm{PCV}(\%)$ & 20.72 & 20.53 & 21.70 & 22.06 & 21.69 & $1.43^{\text {ns }}$ \\
\hline $\mathrm{RBC}\left(\times 10^{12} / \mathrm{L}\right)$ & 1.86 & 1.18 & 1.90 & 1.94 & 1.84 & $0.13^{\text {ns }}$ \\
\hline $\mathrm{WBC}\left(\times 10^{9} / \mathrm{L}\right)$ & $103.00^{\mathrm{b}}$ & $112.16^{\mathrm{ab}}$ & $111.20^{\mathrm{ab}}$ & $111.16^{\mathrm{ab}}$ & $123.23^{\mathrm{a}}$ & $4.27^{*}$ \\
\hline $\mathrm{Hb}(\mathrm{g} / \mathrm{dl})$ & 12.13 & 11.80 & 12.83 & 12.60 & 12.70 & $0.89^{\text {ns }}$ \\
\hline $\operatorname{MCV}(\mathrm{fl})$ & 111.33 & 113.33 & 113.67 & 113.33 & 118.33 & $1.45^{\mathrm{ns}}$ \\
\hline $\mathrm{MCH}(\mathrm{pg})$ & 65.10 & 65.20 & 67.33 & 64.90 & 69.00 & $1.78^{\text {ns }}$ \\
\hline $\operatorname{MCHC}(\%)$ & 58.46 & 57.50 & 59.06 & 57.16 & 58.43 & $1.26^{\mathrm{ns}}$ \\
\hline Neutrophils (\%) & 9.16 & 5.26 & 4.63 & 5.26 & 7.40 & $2.84^{\text {ns }}$ \\
\hline Monocytes (\%) & 20.60 & 21.23 & 16.33 & 17.23 & 22.36 & $2.13^{\text {ns }}$ \\
\hline Lymphocytes (\%) & 70.06 & 73.56 & 79.03 & 77.36 & 70.23 & $3.88^{\text {ns }}$ \\
\hline \multicolumn{7}{|l|}{ Biochemical indices } \\
\hline Protein $(\mathrm{Mg} / \mathrm{dL})$ & $34.00^{\mathrm{a}}$ & $29.33^{\mathrm{b}}$ & $29.33^{\mathrm{b}}$ & $33.33^{\mathrm{ab}}$ & $30.66^{\mathrm{ab}}$ & $1.19^{*}$ \\
\hline Albumin $(\mathrm{g} / \mathrm{dL})$ & 22.36 & 17.43 & 17.29 & 19.80 & 19.56 & $1.48^{\text {ns }}$ \\
\hline Cholesterol (Mg/dL & 135.71 & 135.71 & 130.95 & 123.80 & 121.23 & $9.13^{\text {ns }}$ \\
\hline Creatinine $(\mu \mathrm{Mol} / \mathrm{L})$ & 79.55 & 53.03 & 50.09 & 47.14 & 55.98 & $0.84^{\mathrm{ns}}$ \\
\hline Urea (Mmol/L) & $2.06^{\mathrm{a}}$ & $1.28^{\mathrm{b}}$ & $1.48^{\mathrm{b}}$ & $1.37^{\mathrm{b}}$ & $1.48^{\mathrm{b}}$ & $0.19^{* * *}$ \\
\hline Glucose $(\mathrm{Mmol} / \mathrm{L}$ & $10.53^{\mathrm{bc}}$ & $10.40^{\mathrm{c}}$ & $11.46^{\mathrm{b}}$ & $12.40^{\mathrm{a}}$ & $12.13^{\mathrm{a}}$ & $0.31^{\text {*** }}$ \\
\hline
\end{tabular}

$\mathrm{a}, \mathrm{b}, \mathrm{c}$ means on the same row with difference superscripts are significantly different $*=\mathrm{P}<0.05$, $* * *=$ $\mathrm{P}<0.001, \mathrm{~ns}=$ Not significant, $\mathrm{SEM}=$ Standard error of mean, $\mathrm{PCV}=$ Packed cell volume, $\mathrm{RBC}=$ Red blood cell, $\mathrm{WBC}=$ White blood cell, $\mathrm{MCV}=$ Mean corpuscular volume, $\mathrm{MCH}=$ Mean corpuscular haemoglobin, $\mathrm{MCHC}=$ Mean corpuscular haemoglobin concentration

\section{Discussion}

The chemical composition of TWSSM revealed that it has high protein (CP) content of $20.26 \%$ which was similar to $20 \%$ reported by Nzikou et al. (2009) in Northern Congo, 20.94\% by Agbulu et al. (2010) for black sesame seed in the middle belt of Nigeria and 18-23.18\% reported by Unal and Yalcin (2008) for Turkish sesame. Tunde-Akintunde et al., (2012) however reported a much lower value of 18-19\% CP. These values were however; lower than 25\% reported by Bonchani et al. (2010) for white Sudan sesame seed. The CF content of 9.38\% reported in this study was lower than $18.79 \%$ reported by Agbulu et al. (2010). Several other workers (Nzikon et al. 2010; Warra, 2011; Onsaard, 2012) also reported lower values for CF. Essential amino acid content (EAA) was higher than that reported by NRC (1984), and Cheva-Isaraku and Tangtaweeipiat (1993) in Thailand. It appears therefore that ecological conditions, processing methods and analytical procedures are likely to influence the chemical composition of sesame seed.

Although there was a decrease in average daily weight gain and final weight gain with increased level of toasted white sesame seed meal, the decrease was not significant. This observation agreed with the reports of Agbulu et al. (2010) when they fed black sesame seed meal as replacement for methionine in broiler chickens. Similarly, Diarra and Usman (2008) also reported a slight decrease in weight change from $250.05 \mathrm{~g}$ to $186.40 \mathrm{~g}$ when they fed graded levels of soaked sesame seed meal as a source of methionine. Feed intake range of $78.43 \mathrm{~g}-65.99 \mathrm{~g}$ obtained in this study was influenced by replacement levels. These values however, were lower than $160 \mathrm{~g}$ recommended by Olonu (2011) for finisher broiler chickens. The lower feed intake observed in this study could be attributed to the presence of phytic and oxalic acid content of sesame seed meal (Mamputa and Buhr, 1995) and intensity and or the variety of the sesame seed (Ngele et al. 2011). The FCR which is an index of feed utilization was within the range of 2.82-2.85 recommended by Oluyemi and Roberts (2000) for broiler chickens in warm wet climate. It is however inferior to the range of 1.68-2.16 reported by Oko et al. (2011). The possible explanation could be that the level of sesame seed meal has not been reached to replace synthetic methionine in the diet.

There is an indication that toasting of sesame seed has improved the nutritional and subsequent utilization of the diet as observed by (Prince et al., 1980). All the parameters measured for carcass weight and internal organs characteristics were similar except the abdominal fat which tends to increase with increased level 
of toasted white sesame seed. This findings was contrary to the reports of Agbulu et al. (2010) that observed a significant $(\mathrm{P}<0.05)$ differences in most of the parameters measured for carcass characteristic and internal organs weight. The abdominal fat was observed to increase as the level of sesame seed meal was increased. This could be due to the high content of fat in sesame seed. Sirato-Yesumota et al. (2001) reported that high dietary fat content of sesame seed could lead to excess deposition of adipose tissue. All the internal organs were also not affected by the replacement levels of TWSSM. The fact that none of the internal organs showed any significant difference in size, it means that the test diets did not contain any appreciable toxins that could be detrimental to the organs.

Adejumo (2004) reported that haematological traits especially PCV and $\mathrm{Hb}$ are correlated with the nutritional status of the animal. The values for PCV and $\mathrm{Hb}$ obtained in this study were similar to the values reported by Banerjee (1998). The values for monocytes (16.33-22.36\%), lymphocytes (70.06-79.03\%) and neutrophils (4.63-9.16\%) were however higher than the values reported by Banerjee (1998). The variation in total protein which was significantly higher in treatment 1 shows the superiority of treatment 1 which contains synthetic methionine. Bamgbose et al. (2003) reported that total protein and albumin are indicators of the total protein reserve in an animal body. The values for creatinine were not influenced by the dietary treatments and this indicates the adequacy of protein content in all the diets. Banerjee (1998) in his study on sources and types of protein observed significant variations in serum creatinine and uric acid. The higher values of glucose obtained in this study particularly in treatments 1 (12.40) and 5 (12.13) serves as a source of extra energy to the birds (Mayes, 1996). There was a numerical decrease in cholesterol concentration from $135.71 \mathrm{mg} / \mathrm{dl}$ in treatment 1 to $121.23 \mathrm{mg} / \mathrm{dl}$ in treatment 5. This finding has agreed with the reports of Al-Harthi and El-Deek (2009) who also observed a decrease in cholesterol level as dietary sesame seed meal was increased in the diets. Yamauchi et al. (2006) reported that sesame seed inhibits cholesterol absorption from the intestine and synthesis in the liver. Bamgbose et al. (2011) concluded that such mechanism of inhibiting cholesterol absorption from the intestine will reduce cholesterol deposition in poultry and poultry products which in turn reduces the incidences of coronary heart disease in human following the consumption of these products.

\section{Conclusion}

The use of toasted white sesame seed meal at $16 \%$ gave similar performance with those broiler chickens on synthetic methionine. It can therefore be concluded that toasted white sesame seed meal at $16 \%$ can be used to supplement synthetic methionine without any adverse effect on growth performance broiler chickens.

\section{References}

[1] Adebayo, A. A. (1999). Climate II. In: Adamawa State in Maps. Paracleate publishers, Yola, Nigeria

[2] Adejumo, D.O (2004). Performance, Organ Development and Haematological Indices of rats fed sole diets of graded levels of cassava flour and soybean flour (soygari) as substitutes for energy and protein oncentrates. Tropical Journal of Animal Science, 7: $57-63$

[3] Adejoro, S.O (2004). Poultry Feed Formation in the Tropics. Ibadan, Nigeria: SOAVET Publishers.

[4] Aduku, A.O (1992): Practical Livestock Feeds Production in the Tropics. Asekome and Co. Publishers, Samaru-Zaria, Nigeria Pp: 44-49

[5] Agbulu, A.O., Gyau, A.M and Abakura, J.B (2010). Effect of the Replacement of Sesame Seed for Methionine in Broiler Production in Middle Belt Region-Nigeria. Journal of Emerging Trends in Educational Research and Policy Studies (JETERAPS), 1: 16-21

[6] Al-Harthi, M.A and El-Deek, A.A (2009). Evaluation of Sesame Meal Replacement in Broilers Diets with Phytase and Probiotic Supplementation. Egypt Poultry Science, 29: $\quad 99-125$

[7] Association of Analytical Chemists (1990). Official Methods of Analysis. $13^{\text {th }}$ Edition, Washington D.C, PP: 1018

[8] Bamgbose, A.M., S.O., Nwokoro and O.O Tewe (2003). Serum metabolites and nutrient utilization of fed extruded full fat soya bean diets. Journal of Arid Agriculture. 13; $167-171$

[9] Banerjee, G.C (1998). A textbook of Animal Husbandry. $8^{\text {th }}$ Edition Oxford and IBH Publishing Co. PVT Ltd, New Delhi, India, PP: $393-465$

[10] Biswas, T.K., Sana, N.K., Badal, R.K., and Hugue, E.M (2001). Biochemical Study of Some Oil Seeds (Brassica, Sesame and Linseed) Pakistan Journal Biological Science, 4: 1002-1005

[11] Borchani C., Besbes S., Blecker C. H. \& Attia H. (2010). Chemical Characteristics and oxidative Stability of Sesame Seed, Sesame Paste, and Olive Oils. Journal of Agriculture, Science and. Technology. 12: 585-596

112] Cheva-Isarakal, B. and Tangtaweewipat, S. (1993). Sesame meal as soybean meal substitute in poultry diets. II: Laying hens. AJAS 6(2):253-258

[13] Cooney, R.V. Custer, L.J. Okinaka, L. Franke, A.A (2001). Effects of Dietary Sesame Seeds on Plasma Tocopherol Levels. Nutrition Cancer, 39:66-71

[14] Diarra, S.S and Usman, B.A (2008). Performance of Laying Hens Fed Graded Levels of indicum) Seed Meal as a Source of Methionine. International Journal of Poultry Science

[15] Duncan, D.B (1955). Multiple Range and Multiple F-Test Biometrics. 11, 1-42

[16] Essien, A. Ologhobo, A.D., Akpet, S.S., Ayuk, E.A. and Ibom, L.G(2005). Efficiency of Feed Utilisation of Broiler Chicks Fed Maize-Soybean Diets Supplemeted with Synthetic Methionine and Inorganic Sulphur Source. In: A.O. Fanimo, S.O. Petters, O.M.O. Idowu, S.I. Ola and E.B Sonaya (Eds.). The Emerging Opportunities for Poultry Production in West Africa Proceedings 1st Nigeria International Poultry Summit, February 20 - 25, 2005 Ota, Ogun State, Nigeria, pp: 106-108 
[17] Lamorde, A. G. (1998). Scenario building for the Nigerian Livestock Industry in the 21th silver anniversary conference of the Nigerian Society for Animal Production held at

century. A paper presented at the $26^{\text {th }}$ March, 1998

[18] ]Mamputu, M. And Buhr, R.J (1995). Effect of Substituting Sesame Meal for Soybean Meal on Layer and Broiler Performance. Poultry Science, 74: 672-684

[19] Mayes, P.A (1996). Harper's Biochemistry. $24^{\text {th }}$ Ed., Prentice-Hall International, Inc. New Jersey, USA

[20] ]NAERS (2010). Beniseed production and utilization in Nigeria. Extension Bulletin No. 154. Horticulture series No. 5. Available at www.naers.gov.ng/extmat/bulletins/Business/pdf

[21] Ngele, G.T., Oyawoye, E.O. and Doma, U.D (2011). Performance of Broiler Chickens Fed Raw and Toasted Sesame Seed (Sesamum indicum L) as a Source of Methionine. Continental Journal Agricultural Science, 5: 33-38

[22] NRC (1996). Nutrient Requirement of Domestic Animals, Nutrient Requirement of Poultry, $9^{\text {th }}$ Edition, National Academy Press, Washington, DC.

[23] ]Nzikov, J. M., Matos, I., Bouanga-Kalou, G., Ndongui, C. B., Pambou-Tibi, N. P. G., Kinbonguila, A., Silou, Th., Linder, M. and Desobary, S. (2009). Chemical composition of the seeds and oils of sesame (Sesamum indicum L) grown in Congo-Brazzavile. Advance Journal of Food Science and Technology. 1(1);5-9

[24] Ojiako, O.A., Igwe, C.U., Agha, N.C., Ogbuji, C.A and Onwuliri, V.A (2010). Protein and Amino-acid Composition of Sphenostylis stenocarpa, Sesamum indicum, Monodora myristica and Afzelia Africana Seeds from Nigeria. Pakistan Journal Nutrition. 9: 368372

[25] ]Oko, O. O., K. I. E. Iso., S. P. Udo and J. I. Mbre (2011). Effects of dietary kaolin on the growth performance and serum chemistry of broilers. Nigeria Journal of Animal Science. 13:96-102

[26] Olomu, J.M (2011).Monogastric Animal Nutrition: Principles and Practice. Second Edition, St. Jackson Publishing, Benin City, Nigeria

[27] Oluyemi, J.A. and Roberts, F.A (2000). Poultry Production in Warm Wet Climates. Rev.ed. Spectrum Books Limited, Ibadan, Nigeria, PP:244

[28] Onsaard, E. (2012). Sesame proteins. International Food Research Journal 19(4)1287-1295

[29] Price, M.L., Hagerman, A.E and Butler, L.G (1980). Tannin in Sorghum Grains. Effect of Cooking on Chemical Assays and on Anti-nutritional properties in Rats. Nutrition Report International, 21: 861-867

[30] Sirato-Yasumoto, S.M., Katsuta and Okuyama, Y (2001). Effect of Sesame Seed Rich in Sesamin and Sesamolin on Fatty acid Oxidation in Rat Liver. Journal Agriculture Food Chemistry, 49: 2647-2651

[31] Sirios, M (1995). Mosby's Fundamentals of Veterinary Technique. Veterinary Clinical Laboratory Producers

[32] Steel, R. C. D. and Torrie, J.D. (1980). Priciples and Proccedures of Statistics. McGraw Hills Books Co. New York

[33] Tunde-Akintunde, T. Y., M. O. Oke and B. O. Akintunde (2012). Sesame Seed, Oilseeds, . Uduak G. Akpan (Ed.), ISBN: 978-95351-0665-4, InTech, Available from: http://www.intechopen.com/books/oilseeds/sesameseed

[34] Ulna, M. K. and Yalcin, H (2008). Proximate composition of Turkish sesame seeds and characterization of their oils. GRASAS YACETES 59(1) MARZO ENERC: 23-26

[35] Umeh, G.N and Udo, B.I (2002). Profitability of Poultry Production among School Leavers in Anambra State, Nigeria. Nigeria Journal of Animal Production, 29: 76-80

[36] Warra, A. A. (Sesame seed (sesamum indicum L) seed oil methods of extraction and its prospect in cosmetic industries: A review. Bayero Journal of Pure and Applied Sciences. 4(2):164-168

[37] Yakubu, B., Yusuf, H.B. and Yisa, A.G. (2012) Performance Evaluation of Cockerels fed varying levels of partially germinated Maskwa sorghum cultivar. Adana State University. Journal of Agricultural Sciences. 2(2):50 - 56.

[36] Yamauchi, K., Samanya, M., Seki, K., Ijiri, N. And Thongwitta, N. (2006). Influence of Dietary Sesame Meal Level on Histological Alternatives of the Intestinal Mucosa and Growth Performance of Chickens. Journal of Applied Poultry Research, 15: 266-273 